\title{
Comorbidities associated with maternal mortality from COVID-19 in Mexico
}

\section{Guadalupe López-Rodríguez ${ }^{*}$, Marcos Galván ${ }^{1}$ and Óscar Galván Valencia²}

${ }^{1}$ Nutrition Academic Area, Institute of Health Sciences, Universidad Autónoma del Estado de Hidalgo, Pachuca de Soto, Hidalgo; ${ }^{2}$ Institute of Nutrition, Universidad de la Sierra Sur, Miahuatlán de Porfirio Díaz, Oaxaca. Mexico

\begin{abstract}
Introduction: In Mexico, there is a syndemic in pregnant women, where the epidemic of obesity and chronic diseases coexists with that of coronavirus disease 2019 (COVID-19), which has been associated with a higher risk of maternal mortality. Objective: To evaluate the association of comorbidities during pregnancy with maternal mortality from COVID-19 in Mexico. Material and methods: SISVER COVID-19 databases and epidemiological surveillance reports on maternal mortality were used. Multivariate logistic regression models were used to evaluate the association of comorbidities with maternal deaths from COVID-19. Results: A total of 29,416 pregnant women were evaluated, out of which $39 \%$ were positive for severe acute respiratory syndrome coronavirus 2 (SARS-CoV-2); the risk of maternal mortality was 3.24 times higher $(p<0.01)$ for positive in comparison with negative women. COVID-19 is the leading cause of maternal death since July 2020 and explains more than $50 \%$ of total deaths in 2021. Chronic kidney disease (odds ratio [OR]: $4.11 ; p<0.01$ ) and diabetes (OR: $2.53 ; p<0.01$ ) were the two main comorbidities that were positively associated with maternal death from COVID-19. Conclusion: Comorbidities during pregnancy that are possibly associated with an increase in the inflammatory response and an alteration of the immune response increase the risk of maternal death from COVID-19 in Mexican pregnant women.
\end{abstract}

KEY WORDS: Comorbidity. COVID-19. Maternal mortality. SARS-CoV-2.

\section{Comorbilidades asociadas a mortalidad materna por COVID-19 en México}

\section{Resumen}

Introducción: En México existe una sindemia en las mujeres gestantes, donde coexiste la epidemia de obesidad y enfermedades crónicas con la de enfermedad por coronavirus 2019 (COVID-19), lo que se ha asociado con un mayor riesgo de mortalidad. Objetivo: Evaluar la asociación de las comorbilidades en la mortalidad materna por COVID-19 en México. Material y métodos: Se utilizaron las bases de datos de COVID-19 del SISVER y los reportes de vigilancia epidemiológica de muertes maternas. Se utilizaron modelos de regresión logística multivariante para evaluar la asociación de las comorbilidades durante la gestación con mortalidad materna por COVID-19. Resultados: Se evaluaron 29,416 mujeres embarazadas, el 39\% fueron positivas para coronavirus 2 del síndrome respiratorio agudo grave, el riesgo de mortalidad materna fue 3.24 veces mayor $(p<0.01)$ para las mujeres positivas en comparación con las negativas. La COVID-19 es la primera causa de muerte materna desde julio del 2020 y explica más del 50\% del total de muertes en el 2021. La enfermedad renal crónica (razón de momios [RM]: $4.11 ; p<0.01$ ) y la diabetes (RM: 2.53; $p<0.01$ ) fueron las dos principales comorbilidades asociadas positivamente a la mortalidad materna por COVID-19. Conclusión: Las comorbilidades durante el embarazo posiblemente asociadas con un incremento de la respuesta inflamatoria y alteración de la respuesta inmunitaria incrementan el riesgo de muerte materna por COVID-19 en mujeres gestantes mexicanas.

\section{PALABRAS CLAVE: Comorbilidad. COVID-19. Mortalidad materna. SARS-CoV-2.}

Correspondence:

*Guadalupe López-Rodríguez

E-mail: glopez.dra@gmail.com; glopez@uaeh.edu.mx
Gac Med Mex. 2021;157:599-603

Contents available at PubMed

www.gacetamedicademexico.com

0016-3813/@ 2021 Academia Nacional de Medicina de México, A.C.. Published by Permanyer. This is an open access article under the CC BY-NC-ND license (http://creativecommons.org/licenses/by-nc-nd/4.0/). 


\section{Introduction}

In December 2019, multiple cases of pneumonia of unknown etiology appeared in Wuhan, Hubei province, in China, and a new coronavirus was later identified that was called severe acute respiratory syndrome coronavirus 2 (SARS-CoV-2) ${ }^{1}$. Obesity is one of the main pathologies associated with coronavirus disease 2019 (COVID-19) severe evolution. Worldwide, more than two billion people are estimated to have overweight or obesity ${ }^{2}$, which predisposes them to the development of other chronic pathologies $^{3}$. The National Health and Nutrition Survey (ENSANUT - Encuesta Nacional de Salud y Nutrición) reported in 2018 that, in Mexico, $75.2 \%$ of adults aged 20 years and older have overweight and obesity, out of which $76.8 \%$ are women ${ }^{4}$. Obesity in women is related to a higher risk of cardiovascular diseases, diabetes, hypertension, gynecological disorders ${ }^{5}$ and infectious diseases ${ }^{6}$.

Pregnant women are more likely to suffer complications and diseases caused by infections, including that by SARS-CoV-2. Owing to this, pregnant women are a vulnerable group during any health emergency ${ }^{7}$, given that, during pregnancy, there are physiological changes characterized by an immune response adaptation $^{8}$, which increases the risk and severity of infections. In addition, during pregnancy there is a physiological accumulation of adipose tissue that is associated with an increase in inflammatory response $^{9}$, which is higher if there is pre-pregnancy obesity $^{10}$.

In pregnant women, SARS-CoV-2 can cause complications such as abortions, fetal growth restriction and preterm birth, which increases the risk of fetal distress and maternal death ${ }^{11}$. In Mexico there are no reports on comorbidities associated with maternal deaths; therefore, the purpose of this study was to evaluate the association between comorbidities during pregnancy and the risk of mortality in pregnant women diagnosed with COVID-19.

\section{Methodology}

In this study, the National System for Viral Respiratory Diseases Epidemiological Surveillance (SISVER - Sistema Nacional de Vigilancia Epidemiológica de Enfermedades Respiratorias Virales) open database was used to identify cases of COVID-19 in Mexico available by February $2,2021^{12}$, as well as the
Epidemiological Surveillance Weekly Reports on Maternal Deaths for $2020^{13}$ and $2021^{14}$. On SISVER database, all pregnant women with laboratory analysis to detect the presence of SARS-CoV-2 with a molecular test using the polymerase chain reaction (PCR) method were selected ${ }^{15}$.

Descriptive analyses of the main characteristics of interest were carried out. Categorical variables were described as percentages. Multivariate logistic regression tests were performed for the association of maternal mortality with the diagnoses of diabetes, hypertension $(\mathrm{HT})$, chronic obstructive pulmonary disease (COPD), asthma, immune, cardiovascular, chronic kidney disease (CKD) and obesity recorded on SISVER database. In addition, bivariate logistic regression models were used to associate maternal mortality with SARS-CoV-2-positive tests; maternal age and comorbidities were included in the analysis for estimating the odds ratio (OR) and $95 \%$ confidence intervals (Cl). A p-value $<0.05$ was considered to be statistically significant. Data analysis was carried out using the SPSS statistical package, version 21 (SPSS Corp., Chicago, IL, USA).

\section{Results}

A total of 11,488 records of SARS-CoV-2-positive women and 17,928 with a negative result were evaluated, with positivity percentage being $39 \%$. Mortality OR of pregnant women with a SARS-CoV-2-positive test was 3.24 (95\% Cl: 2.3-4.5) in comparison with pregnant women with negative test results. Figure 1 shows the cumulative number of maternal deaths from COVID-19 in Mexico, which by March 8, 2021 was 304 deaths, out of which 202 were recorded in 2020 and 102 in 2021. In 2020, the first two cases were recorded on epidemiological week 15 and accounted for $1.3 \%$ of total causes of death; by week 28, COVID-19 became the leading cause of death $(17.5 \%$ of total). From epidemiological week 33 to 53 , the percentage of deaths from COVID-19 remained at around $22 \%$. Since the beginning of 2021, there was a sudden increase in the number of COVID-19-associated confirmed maternal deaths (Fig. 2), which accounted for $61.3 \%$ of maternal deaths at epidemiological week 1 and, by epidemiological week 14 , the rate is close to $50 \%$ (Fig. 1).

Table 1 shows the comorbidities associated with maternal mortality. In model 1 , the diseases that were associated with a higher risk of COVID-19-associated mortality were observed to be CKD (OR: 
Table 1. Maternal mortality odds ratio by pathology in Mexican pregnant women diagnosed with coronavirus disease 2019 (COVID-19)

\begin{tabular}{|c|c|c|c|c|c|}
\hline \multirow[t]{2}{*}{ Disease } & \multirow[t]{2}{*}{ Cases } & Deceased & Non-deceased & Model 1 & Model 2 \\
\hline & & \multicolumn{2}{|c|}{ N (\%) } & \multicolumn{2}{|c|}{ OR (95\% Cl) } \\
\hline Diabetes & 377 & $16(13.2)$ & $361(3.2)$ & $3.47(1.9-6.0)$ & $2.53(1.4-4.7)$ \\
\hline HT & 338 & $13(10.7)$ & 325 (2.9) & $2.87(1.5-5.3)$ & $1.50(0.7-3.1)$ \\
\hline COPD & 17 & $0(0)$ & $17(0.1)$ & - & - \\
\hline Asthma & 247 & $5(4.1)$ & $242(2.1)$ & $1.96(0.8-4.8)$ & $1.57(0.6-4.2)$ \\
\hline Immune & 85 & $1(0.8)$ & $84(0.7)$ & $1.09(0.1-7.9)$ & $0.36(0.04-3.2)$ \\
\hline Cardiovascular & 51 & $0(0)$ & $51(0.4)$ & - & - \\
\hline Chronic renal & 34 & $3(2.5)$ & $31(0.3)$ & $7.47(2.2-25.3)$ & $4.11(1.04-16.3)$ \\
\hline Obesity & 902 & $21(17.2)$ & $881(7.8)$ & $2.27(1.4-3.7)$ & $1.72(1.02-2.9)$ \\
\hline
\end{tabular}

OR: odds ratio; $\mathrm{Cl}$ : confidence interval; $\mathrm{HT}$ : hypertension; COPD: chronic obstructive pulmonary disease.

*Table prepared with records from February 2, 2021 report $^{12}$. Total recorded number of deceased women was 122, and 11,346 non-deceased. In model 1, adjustments were made for maternal age, and in model 2, for maternal age and all model 1 comorbidities.

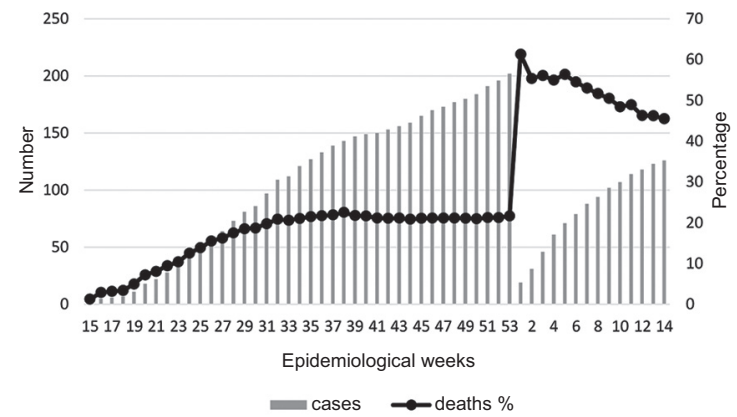

Figure 1. Cumulative maternal deaths from coronavirus disease 2019 (COVID-19) in Mexico, 2020 and 2021. Data on the bars represent the number of COVID-19 cumulative cases. The line indicates the percentage of COVID-19-associated maternal deaths with regard to total deaths recorded by epidemiological week. Report by April 12, 2021.

7.47; 95\% Cl: 2.2-25.3), followed by diabetes (OR: $3.47 ; 95 \% \mathrm{Cl}$ ): $1.9-6.0$ ) and HT (OR: $2.87 ; 95 \% \mathrm{Cl}$ : 1.5-5.3) with a risk of $7.47,3.47$ and 2.87 , respectively (model $1, p<0.05$ ). However, in model 2 , the association is only preserved for diabetes (OR: 2.53; 95\% Cl: 1.4-4.7), obesity (OR: $1.72 ; 95 \% \mathrm{Cl}: 1.02-$ 2.9) and CKD (OR: 4.11; 95\% Cl: 1.04-16.3). COPD and cardiovascular disease were not associated with mortality risk in pregnant women with a SARS-CoV2-positive diagnosis.

\section{Discussion}

In the present study, a positive association was observed between the presence of chronic diseases during pregnancy and a higher likelihood of death from

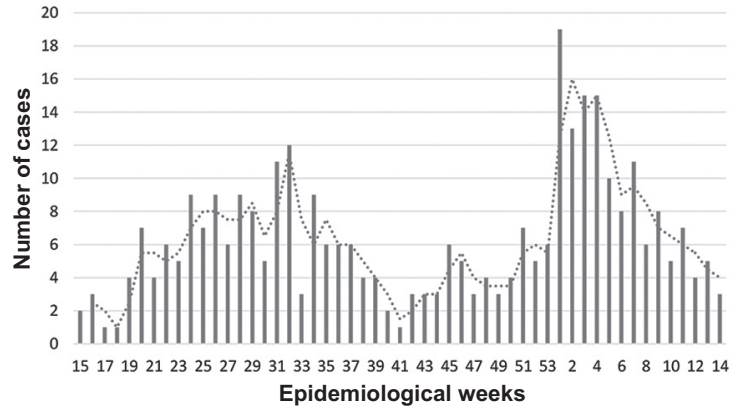

Figure 2. Cases of coronavirus disease 2019 (COVID-19) in Mexico, 2020 and 2021. Data on the bars represent the number of COVID19 confirmed cases. Prepared with data from 2020 epidemiological weeks' reports (starting from week 15) and until 2021 epidemiological week 14.

COVID-19. In pregnant women, there is controversy regarding the risk of complications and death from COVID-19, since the first studies in Mexico indicated that pregnancy did not imply a higher risk when compared to non-pregnant women ${ }^{16}$; however, the latest reports in Mexico $0^{17,18}$ and other countries show the opposite $^{19}$. In Mexico, COVID-19 is a life-threatening condition: in this study, an OR of $3.24(p<0.001)$ was identified in pregnant women; COVID-19 is characterized for decreasing lymphocytes and increasing pro-inflammatory cytokines, which is also observed during pregnancy, in addition to the fact that the placenta has receptors for angiotensin-converting enzyme (ACE) $2^{20}$, which together would potentiate the risk of complications and death associated with SARS-CoV-2 infection. 
Mortality from infection is also associated with the comorbidities pregnant women have, with kidney disease being the condition that showed the highest risk (OR: $4.11 ; 95 \% \mathrm{Cl}$ : $1.3-23.6)$. In a previous study, an OR of 2.25 (95\% Cl: 1.04-16.3) was observed in Mexican women with COVID-1921, and of 1.99 (95\% Cl: 1.9-2.1) in the general population. However, in the present study, the risk was observed to be much higher when women are pregnant. This is possibly associated with the state of immunosuppression that has been identified in patients with chronic kidney disease ${ }^{22}$, in addition to the fact that many of these patients are treated with ACE1 inhibitors and angiotensin receptor blockers, due to renin-angiotensin-aldosterone system increased activity, which increases ACE2 expression in the liver and heart ${ }^{23}$.

In Mexico, obesity is the main comorbidity associated with the risk of COVID-19 severe manifestations ${ }^{24}$ and death ${ }^{25}$, which is not confirmed in the evaluated pregnant women, in whom diabetes and CKD are the main risks associated with mortality. This result has limitations, since obesity evaluation and diagnosis during pregnancy should be carried out by an expert, and in this study it was self-reported. However, these results highlight the importance of these diseases within the global burden of disease in the Mexican population.

\section{Conclusions}

COVID-19 is the main cause of maternal mortality in Mexico since the second week of July 2020, and one year after the beginning of the pandemic it continues in the same place, accounting for $27 \%$ of maternal deaths. By March 2021, COVID-19 infections in pregnant women, which correspond to the second wave, are declining.

CKD, diabetes and obesity have an important effect on COVID-19-associated maternal mortality in Mexico. These pathologies are associated with a higher inflammatory response and an alteration of the immune response, which, associated with pregnancy, would potentiate the risks of serious forms and death from SARS-CoV-2 infection.

\section{Funding}

This research has not received specific aid from agencies of the public, commercial or private sectors.

\section{Conflict of interests}

The authors declare that they have no conflicts of interest.

\section{Ethical disclosures}

Protection of human and animal subjects. The authors declare that no experiments were performed on humans or animals for this research.

Confidentiality of data. The authors declare that no patient data appear in this article.

Right to privacy and informed consent. The authors declare that no patient data appear in this article.

\section{References}

1. Zhu N, Zhang D, Wang W, Li X, Yang B, Song J, et al. A novel coronavirus from patients with pneumonia in China, 2019. N Engl J Med. 2020;382(8):727-33.

2. Caballero B. Humans against Obesity: Who will win? Adv Nutr. 2019:10(Suppl 1):S4-S9.

3. Saltiel AR, Olefsky J. Inflammatory mechanisms linking obesity and metabolic disease. J Clin Invest. 2017;127(1):1-4.

4. Encuesta Nacional de Salud y Nutrición 2018-19. Resultados nacionales [Internet]. Mexico: Centro de Investigación en Evaluación y Encuestas. Available at: https://ensanut.insp.mx/encuestas/ensanut2018/informes.php

5. Tauqeer Z, Gomez G, Stanford FC. Obesity in women: Insights for the clinician. J Womens Health (Larchmt). 2018;27(4):444-57.

6. Fezeu L, Julia C, Henegar A, Bitu J, Hu FB, Grobbee DE, et al. Obesity is associated with higher risk of intensive care unit admission and death in influenza $A$ (H1N1) patients: a systematic review and meta-analysis. Obes Rev. 2011;12(8):653-59.

7. López-Rodríguez G, Álvarez J, Galván M, Montiel-Hernández R. Embarazo y COVID-19, un enfoque preventivo para la salud nutricional. Educación y Salud. Boletín Científico Instituto de Ciencias de la Salud Universidad Autónoma del Estado de Hidalgo. 2020:9(17):45-53.

8. Soma-Pillay P, Nelson-Piercy C, Tolppanen H, Mebazaa A. Physiological changes in pregnancy. Cardiovasc J Afr. 2016;27(2):89-94.

9. Ovalle A, Martínez MA, Fuentes A, Marques X, Vargas F, Vergara $P$, et al. Obesity, a risk factor for ascending bacterial infection during pregnancy. Rev Med Chile. 2016;144(4):476-82.

10. Zacarias MF, Collado MC, Gomez-Gallego C, Flinck H, Aittoniemi J, Isolauri $\mathrm{E}$, et al. Pregestational overweight and obesity are associated with differences in gut microbiota composition and systemic inflammation in the third trimester. PLoS One. 2018;13(7):e0200305.

11. Panahi L, Amiri M, Pouy S. Risks of novel coronavirus disease (COVID-19) in pregnancy; a narrative review. Arch Acad Emerg Med. 2020;8(1):34.

12. Secretaría de Salud. Bases de datos COVID 19 en México 2021 [Internet]. Gobierno de México, Secretaría de Salud. Available at: https:// datos.gob.mx/busca/dataset/informacion-referente-a-casos-covid-19-en-mexico

13. Secretaría de Salud. Informes Semanales para la Vigilancia Epidemiológica de Muertes Maternas 2020 [Internet]. Gobierno de México, Secretaría de Salud; 2020. Available at: https://www.gob.mx/salud/documentos/ informes-semanales-para-la-vigilancia-epidemiologica-de-muertes-maternas-2020

14. Secretaría de Salud. Informes Semanales para la Vigilancia Epidemiológica de Muertes Maternas 2021 [Internet]. Gobierno de México, Secretaría de Salud; 2021. Available at: https://www.gob.mx/salud/documentos/ informes-semanales-para-la-vigilancia-epidemiologica-de-muertes-maternas-2021

15. Tang YW, Schmitz JE, Persing DH, Stratton CW. Laboratory diagnosis of COVID-19: Current issues and challenges. J Clin Microbiol. 2020;58(6):e00512-20.

16. Rios-Silva M, Murillo-Zamora E, Mendoza-Cano O, Trujillo X, Huerta M. COVID-19 mortality among pregnant women in Mexico: A retrospective cohort study. J Glob Health. 2020;10(2):020512. 
17. Martinez-Portilla RJ, Sotiriadis A, Chatzakis C, Torres-Torres J, Espino YSS, Sandoval-Mandujano K, et al. Pregnant women with SARS-CoV-2 infection are at higher risk of death and pneumonia: propensity score matched analysis of a nationwide prospective cohort (COV19Mx). Ultrasound Obstet Gynecol. 2021:57(2):224-31.

18. Martinez-Portilla RJ, Smith ER, He S, Torres-Torres J, Espino YSS, Solis-Paredes JM, et al. Young pregnant women are also at an increased risk of mortality and severe illness due to coronavirus disease 2019: analysis of the Mexican National Surveillance Program. Am J Obstet Gynecol. 2021;224(4):404-7.

19. Subbaraman N. Pregnancy and COVID: what the data say. Nature. 2021:591(7849):193-5.

20. Phoswa WN, Khaliq OP. Is pregnancy a risk factor of COVID-19? Eur J Obstet Gynecol Reprod Biol. 2020;252:605-9.

21. Hernández-Garduño $E$. Obesity is the comorbidity more strongly associated for Covid-19 in Mexico. A case-control study. Obes Res Clin Pract. 2020;14(4):375-9.
22. Girndt M, Sester M, Sester U, Kaul H, Kohler H. Molecular aspects of T- and B-cell function in uremia. Kidney Int Suppl. 2001;78:S206-11.

23. Jessup JA, Gallagher PE, Averill DB, Brosnihan KB, Tallant EA, Chappell MC, et al. Effect of angiotensin II blockade on a new congenic model of hypertension derived from transgenic Ren-2 rats. Am J Physiol Heart Circ Physiol. 2006;291(5):H2166-72.

24. Denova-Gutiérrez E, López-Gatell H, Alomía-Zegarra JL, López-Ridaura R, Zaragoza-Jiménez CA, Dyer-Leal DD, et al. The association of obesity, type 2 diabetes, and hypertension with severe coronavirus disease 2019 on admission among Mexican patients. Obesity (Silver Spring). 2020;28(10):1826-32.

25. Bello-Chavolla OY Bahena-López JP, Antonio-Villa NE, Vargas-Vázquez A, González-Díaz A, Márquez-Salinas A, et al. Predicting mortality due to SARS-CoV-2: A mechanistic score relating obesity and diabetes to COVID-19 outcomes in Mexico. J Clin Endocrinol Metab. 2020;105(8):dgaa346. 